that we may discover additional volumes at a later date. Thus, supplements to this bibliography will be inevitable. A supplement containing entries for the war years, 1941-45, will also be published.

The arrangement of entries is by broad subjects, and within each subject alphabetically by author. Each entry is numbered. On the whole it can be said that this work has been executed in conformity with sound bibliographical principles, and when complete, it will be of great value for Yugoslav scholars as well as for others who are familiar with the Serbo-Croatian language and are interesed in the literatures and cultures of the Yugoslav people.-Milimir Drazic, University of Kentucky Library.

\section{Printing and Publishing}

\section{in Alsace}

Histoire de l'imprimerie alsacienne aux XVe et XVIe siècles. Par François Ritter, Strasbourg-Paris: F.-X. Le Roux, 1955. xvi, 631p. (Publications de l'Institut des Hautes Études Alsaciennes, Vol. 14.)

It takes some daring to attempt a comprehensive study of the complex history of printing and publishing in Alsace during the fifteenth and sixteenth centuries. Problems involved touch on so many facets of cultural and social history that it becomes difficult to master the variety of topics and to evaluate the considerable literature; it is difficult also to add substantial and new information to competent studies like Charles Schmidt's Histoire littéraire de l'Alsace (1879), Karl Schorbach's Der Strassburger Frühdrucker Johann Mentelin (1932), or Paul Kristeller's Die Strassburger Buchillustration im XV. und im Anfang des XVI. Jahrhunderts (1888).

Yet the task is highly worth while. Alsace in general, and Strasbourg in particular, are key areas in the study of fifteenth and sixteenth century history. Publishing there provides dramatic illustrations for the slow disappearance of the medieval world, the growth of humanism and its new learning, the religious controversies before and during the Reformation, the interest in Germany's medi- eval vernacular literature possibly to be interpreted as the by-product of rising nationalism, the increased production of contemporary literature, including some rather bawdy writings for popular entertainment, the accomplishments of city-sponsored secular education, the development of modern science paralleled by the publication of handbooks for craftsmen, and the use of book illustrations to make the products of the press more attractive and more saleable, and also better understood.

François Ritter, well known to the historian of early printing through the compilation of the Répertoire des livres alsaciens du XVIe siècle de la Bibliothèque nationale de Strasbourg (1932-), the Catalogue des incunables alsaciens de la Bibliothèque nationale de Strasbourg (1938), and the Catalogue des incunables et des livres du XVIe siècle de la Bibliothèque municipalede Strasbourg (1948), and known to literary historians as the coauthor with Paul Heitz of the small but extremely useful Versuch einer Zusammenstellung der deutschen Volksbücher des 15. und 16. Jahrhunderts (1924) is well qualified to follow in the steps of the venerable Charles Schmidt and to write a comprehensive history of Alsatian printing and publishing.

His history of Alsatian printing is divided into two main parts. Part I covers the fifteenth century. In its first chapter the author surveys the literature on the Gutenberg question with its complicated and at times highly speculative controversies over the chronology of events preceding the publication of the 42 line Bible (including the most recent discussion over the Missale speciale). When he discusses the part which Strasbourg may have played in Gutenberg's early attempts, the author naturally shows his patriotic feelings and justifiable bias, without accepting, however, suspect evidence, like the early sixteenth century claim that the Strasbourg printer Mentelin was the real inventor of the ars nova. Chapters two to six deal with the earliest Strasbourg printers, Mentelin, Eggestein, Rusch, and others. Chapter seven, the last of Part I, is devoted to Alsatians who sought their fortunes away from home, among them Sixtus Riesinger (Naples), Michael Friburger (Paris, where he established the first press in France together with Gering and Crantz), 
Reinhart (Lyons) and Wenssler (in nearby Basel).

Throughout Part I the author presents, and then carefully sifts, available information; he pays much attention to the connection between printers in Strasbourg, their colleagues abroad and their learned friends; he supplies data on bookmaking techniques and illustrations, which then added much to the success and fame of Strasbourg publishing. These and similar points are even more important in Part II, which is devoted to the sixteenth century. Famous men like Sebastian Brant, Geiler von Kaisersperg, Thomas Murner, Martin Luther, Philip Melanchthon, Desiderius Erasmus, and Otto Brunfels appear again and again on these pages.

The first six chapters of Part II systematically discuss the character and activities of Strasbourg sixteenth century enterprises. The author supplies biographical data, often adding to, and correcting, earlier studies; he apparently made excellent use of archival sources to which we find numerous references. Important titles, where formerly ascribed to the wrong presses, are reassigned; the relations between printers and correctors, editors, authors, government and church authorities, and artists are fully treated, and every statement is well documented and copiously annotated. Indeed, the so-called "appendices" (491 in number and covering pages 485 to 595) are full of information and often prove instructive, even though they seem at times unnecessary or superabundant.

The seventh chapter of the second part is devoted in its entirety to French printing in Strasbourg (in the preceding chapters François Ritter had spoken of the interesting Reformation tracts in English, produced away from England in a town which, in spite of rigid trade regulations, had until the middle of the sixteenth century shown a liberal attitude towards all sides of the religious struggles). The eighth and ninth chapters cover the less prolific printing establishments in Haguenau, Colmar, Sélestat, Mulhouse and Lauffen. The final chapter is devoted to six outstanding book illustrators: Wechtelin, Urs Graf, Weiditz, Baldung Grien, Schäufelein and Tobias Stimmer. In conclusion there is a summary "sur l'histoire de l'imprimerie en Alsace ... et ses réactions dans les divers domaines de la vie sociale," final evidence of the author's concern with printing not as a separate phenomenon but as part of the entire social and intellectual history.

Though filled with facts, and some figures, this book makes (in most parts) for enjoyable reading. Ritter avoids monotonous enumerations and generally prefers an easily flowing narrative style. Some arguments may seem overly spirited; this only added to this reader's pleasure. Without making an effort, we noticed a few misprints, but this would seem well-nigh unavoidable in this type of study.

In summary, the Histoire de l'imprimerie alsacienne is an excellent book which will prove to be very useful to students of the intellectual history of our early modern times. We regret that its value as a reference book is somewhat diminished by the absence of a subject or topical index; however, it does contain a careful index of authors and publisherprinters.-Rudolf Hirsch, University of Pennsylvania Library.

\section{OTTO HARRASSOWITZ}

Library Agent since 1872, supplies books and periodicals published in West and East Germany and adjacent countries. Orders and inquiries are invited on both new and out=ofprint material.

\section{OTTO HARRASSOWITZ WIESBADEN}

Farmington Plan Agent for Germany

Please mention $C$ \& $R L$ when corresponding with its advertisers. 